\title{
Pest Management Challenges and Control Practices in Codling Moth: A Review
}

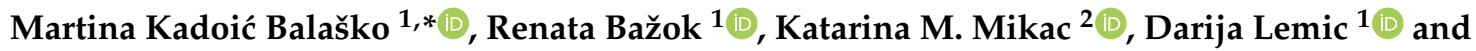 \\ Ivana Pajač Živković ${ }^{1}$ (D) \\ 1 Department for Agricultural Zoology, Faculty of Agriculture, University of Zagreb, Svetošimunska \\ 25, Zagreb 10000, Croatia; rbazok@agr.hr (R.B.); dlemic@agr.hr (D.L.); ipajac@agr.hr (I.P.Ž.) \\ 2 Centre for Sustainable Ecosystem Solutions, School of Earth, Atmospheric and Life Sciences, Faculty of \\ Science, Medicine and Health, University of Wollongong, Wollongong 2522, Australia; kmikac@uow.edu.au \\ * Correspondence: mmrganic@agr.hr; Tel.: +385-1-239-3654
}

Received: 14 November 2019; Accepted: 31 December 2019; Published: 3 January 2020

\begin{abstract}
The codling moth, Cydia pomonella L., is a serious insect pest in pome fruit production worldwide with a preference for apple. The pest is known for having developed resistance to several chemical groups of insecticides, making its control difficult. The control and management of the codling moth is often hindered by a lack of understanding about its biology and ecology, including aspects of its population genetics. This review summarizes the information about the origin and biology of the codling moth, describes the mechanisms of resistance in this pest, and provides an overview of current research of resistant pest populations and genetic research both in Europe and globally. The main focus of this review is on non-pesticide control measures and anti-resistance strategies which help to reduce the number of chemical pesticides used and their residues on food and the local environment. Regular monitoring for insecticide resistance is essential for proactive management to mitigate potential insecticide resistance. Here we describe techniques for the detection of resistant variants and possibilities for monitoring resistance populations. Also, we present our present work on developing new methods to maintain effective control using appropriate integrated resistance management (IRM) strategies for this economically important perennial pest.
\end{abstract}

Keywords: codling moth; resistance mechanisms; genetics; control strategies; anti-resistance program; geometric morphometrics; SNPs

\section{Introduction}

Origin and Biology of the Codling Moth, Cydia pomonella

The codling moth (CM) (Cydia pomonella L.) is a key pest in most pome fruit orchards in Croatia and worldwide. This pest, besides apple, also is a pest of pear, walnut, quince and some stone fruits where it causes economic losses in fruit production [1]. Balachowsky and Mesnil [2] were the first to mention CM, and provided data on its origin and damages caused to fruit historically. In Croatia, according to Kovačević [3], CM has been present since ancient times. In North America, it is known that the pest was introduced ca. 1750 [4]. CM was originally from Eurasia, most likely Kazakhstan, but interestingly it was not reported in China until 1953 [5]. Over the last two centuries it dispersed globally with the cultivation of apples and pears. Currently, CM is present in South America, South Africa, Australia and New Zealand [6]. CM occurs in almost every country where apples are grown, and it has achieved a nearly cosmopolitan distribution, being one of the most successful pest insect species known today [7].

CM adults are small ( 10 $\mathrm{mm}$ in length). They can be distinguished from other moths associated with fruit trees by their dark brown wingtips that have shiny, coppery markings [8]. It overwinters 
as a fully grown larva within a thick, silken cocoon that can be found under loose scales of bark and in the soil or debris around tree bases [9]. The larvae pupate inside their cocoons in early spring when temperatures exceed $10{ }^{\circ} \mathrm{C}$. Depending on ambient temperature, pupal development occurs within 7-30 days. For the development of adults, the sum of 100 degree-days measured from the 1st of January are required [10]; this value is usually attained at the end of April (i.e., northern hemisphere growing season). For one whole generation of $\mathrm{CM}$, the sum of 610 degrees is required for the complete development of the insect, i.e., from eggs until the appearance of adult moths [10]. A second generation appears after ten days and its flight and egg laying lasts from mid-July to mid-August. Diapausing larvae overwinter in their hibernacula, pupate and then emerge the following spring [11].

The CM has adapted successfully to different habitats by forming various ecotypes, often designated by the term 'strains', which differ among each other in several morphological, developmental and physiological features [12]. On apples and pears, larvae penetrate fruit and bore into the core, leaving brown-colored holes in the fruit that are filled with frass (larval droppings) [8]. If chemical treatment is not used during production, CM can cause a decrease in apple harvest from $30 \%$ up to $50 \%$. For apples, intensive production tolerates $1 \%$ of infested fruit. Producers, with various methods of fruit protection, try to lower that number below $0.5 \%[1,3]$.

Depending on the cultivation area and climatic conditions, the pest develops one to four generations/year. According to Neven [13,14], CM diapause can be facultative and depends on both photoperiod and temperatures. The overwintering generation emerges synchronously in the spring followed by one to two slightly overlapping emergence peaks later on in the season. The CM life cycle can be affected by temperature and day length, resulting in different emergence patterns. Pajač et al. [15] confirmed that there is a possibility that an additional (third) generation of the pest can develop in Croatia in years in which the sum of degree-days is higher than the average. CM abundance cannot be explained by any single ecological factor [16]. Following the dynamics and abundance of CM adults over a 10-year period (2000-2009) Pajač and Barić [17] observed marked differences in their population dynamics. Their research confirmed the earlier appearance of adults in the early season and associated longer flight times. Also, the total number of adults caught in pheromone traps increased as the maximum daily number of moths caught per trap also increased. As the climate has changed and higher daily and annual temperatures are recorded, it is thought that this has a resulting impact on the biology of this pest. It is this global phenomenon coupled with chemical-resistant CM biotypes that could be responsible for the longer flight period and observed overall increase in abundance of CM.

\section{Insecticides Resistance}

In apple orchards, $70 \%$ of insecticides used are to control CM [6]. CM control is achieved using various neuroactive products such as organophosphates, carbamates, synthetic pyrethroids, neonicotinoids, and insect growth regulators (IGR). The CM is a very plastic species and easily adapts to different climatic conditions including the development of resistance to various groups of synthetic insecticides in the USA and Europe [6,18-20]. According to May and Dobson [21], the spread of resistance in insect populations depends on multiple factors, including: the intensity of insecticide selection pressure, the migration ability of individuals, and the fitness costs linked with resistance. In the $\mathrm{CM}$, the first case of resistance recorded was to arsenates in 1928 in the USA [22]. Since then, new cases of resistance have been reported in almost all of the main apple-growing regions worldwide [18,23-25]. During the 1980s and 1990s CM control in Europe was achieved using broad spectrum insecticides (pyrethroids and organophosphates [OP]), however, the evolution of pesticide resistance efficacy for these insecticides diminished quickly $[18,20,26,27]$. Reyes et al. [28] states that insecticide resistance in CM in Europe was first detected ca. 1990 to diflubenzuron (in Italy and southeastern France); further pesticide control failures were observed in Switzerland and Spain. CM populations are now resistant to neonicotinoids including environmentally friendly avermectins [28]. Further, $\mathrm{CM}$ has developed resistance to azinphos-methyl and tebufenozide in post-diapausing larval stages, to OP [29] insecticides and more recently to insect growth regulators (IGRs). Resistance is mainly associated 
with the detoxification system's mixed-function oxidases (MFO), glutathione-S-transferases (GST) and esterases (EST) $[18,28,30]$. A kdr mutation in the voltage-dependent sodium channel is involved in resistance to pyrethroids [31] and an acetylcholinesterase (AChE) mutation has been identified in a laboratory strain selected for resistance to azinphos-methyl [32]. Evidently, the last 20 years' usage of chemical insecticides has modified the development of resistance [6]. An additional problem appeared in the mid-1990s with the development of cross-resistance due to the CM becoming resistant to several chemical groups of insecticides simultaneously [33].

Bosch et al. [34] determined the efficacy of new versus old insecticides against the CM in Spain. In their bioassays, they used 10 different active ingredients on twenty field populations of CM. Very high resistance ratios were detected for methoxyfenozide and lambda-cyhalothrin, while $50 \%$ of the populations were resistant or tolerant to thiacloprid. Tebufenozide showed very good efficacy in all the field trials. Even though CM showed resistance to chlorpyrifos-ethyl because of its widespread use, in this trial it was effective against CM populations. All other insecticides (indoxacarb, spinosad, chlorantraniliprole, emamectin, and spinetoram) provided high efficacy. These results showed that resistant CM populations in Spain can be controlled using new reduced-risk insecticides [34]. The newest and, at the same time, the first study of insecticide resistance and analysis about its resistance status in China showed insensitivity to chlorpyrifos-ethyl and carbaryl [35]. The first study of insecticide resistance in Greece showed reduced susceptibility to major groups of insecticides which were included in bioassays (azinphos-methyl, phosalone, deltamethrin, thiacloprid, fenoxycarb, tebufenozide, methoxyfenozide and diflubenzuron). But, also important, known target-site resistance mechanisms (kdr and modified AChE) were not detected [36].

Baculoviruses are insect pathogenic viruses that are widely used as biological control agents of insect pests in agriculture. One of the most important commercially used baculoviruses is the Cydia pomonella granulovirus (CpGV) [37]. For more than 30 years, commercial CpGV products have been successfully applied to control CM in organic and integrated fruit production. For all European CpGV products, the original Mexican isolate described by Tanada in 1964, CpGV-M, has been used [37]. According to Harison and Hoover [38], a granulovirus (GV) was identified from CM cadavers and found to be a type $2 \mathrm{GV}$ that killed larvae in three to four days at higher concentrations. After promising field tests as a control measure in 1968 and 1977 [39,40], CpGV was developed into several control products in Europe and in North America. CpGV is used to control CM on over 100,000 ha of organic and conventional apple orchards in Europe [41,42]. Since 2005, resistance against the widely used isolate CPGV-M has been reported from different countries in Europe [41,43,44]. In a multination monitoring program, Schulze-Bopp and Jehle [45] identified that $70 \%$ of $\mathrm{CM}$ were resistant or partly resistant to CpGV across multiple orchards in Germany, Austria, Switzerland, Italy, and the Netherlands. The recent research by Sauer et al. [46] described autosomal and dominant inheritance of this resistance and demonstrated cross-resistance to different CPGV genome groups. The same authors report a CM field population with a new type of resistance, which appears to follow a highly complex inheritance in regards to different CpGV isolates [47]. In the European Union (EU) there are no strategic integrated pest management (IPM) programs that solve the current confusion surrounding $\mathrm{CM}$ control and resistance. There is a need for new control tools and a fresh approach to CM control and management in the EU.

\section{Present Strategies in Codling Moth Suppression}

\subsection{Mechanical Control}

Because of resistance development in CM populations, there is a need for alternatives to insecticides and CpGV. In recent studies, special attention is given to insect exclusion netting systems in apple production. The first netting system was designed in France in 2005 and in 2008 it was introduced in Italy. In both countries, a high level of efficacy of nets was observed against CM, especially for the 'single-row' system, which the authors recommend because it was more efficient and more durable than 
the 'whole-orchard' version. Also, this method enables a significant reduction in pesticide use without any major risks for apple production [48]. Pajač Živković et al. [49] tested the effectiveness of insect exclusion netting systems in preventing the attack of CM on apple fruits in Croatia. The authors showed a significant reduction in CM catches and also fruit injury compared to the non-netted control. This is consistent with similar studies in which nets significantly reduced the number of CM catches [50,51]. Modifying the orchard microclimate and reducing the interception of light using netting systems could have a negative consequence on the organoleptic quality of apple fruit according to Baiamonte et al. [52]. While the netting system prevents the entry of insect pests, it also serves as a barrier to beneficial insects (e.g., ladybugs, true bugs and syrphid flies) which could negatively affect natural pest control services. [49]. Alaphilippe et al. [48] recommend, due to the cost and constraints of netting, that this method be used in areas where CM is difficult to control.

\subsection{Chemical Control}

Chemical control of CM is still the main method used in integrated pome fruit production [53]. According to the Insecticide Resistance Action Committee (IRAC) [54] for CM control in most countries, there are 11 modes of action (MoA) available on the market depending on the country. For CM, some insecticides affect the nervous system, or pest growth and development. Acetylcholinesterase inhibitors (carbamates and organophosphates), sodium channel modulators (pyrethroids), nicotinic acetylcholine receptor agonists (neonicotinoids), nicotinic acetylcholine receptor agonists allosteric modulators (spinosyns), chloride channel activators (avermectins), voltage-dependent sodium channel blockers (oxadiazines) and ryanodine receptor modulators (diamides) all affect the pest's nervous system; these insecticides are fast-acting [54]. Juvenile hormone mimics (phenoxyphenoxy-ethylcarbamate), chitin biosynthesis inhibitors - type 0 (benzonylureas) and ecdysone agonists (diacylhydrazines) all affect pest growth and development [54]. Insect development is controlled by juvenile hormones and ecdysone by directly perturbing cuticle formation/deposition or lipid biosynthesis. Such insect growth regulators are generally slow to moderately-slow acting [54].

From ca. the 1890s until today, insecticide groups and active substances used for CM suppression have been rapidly evolving. As can be seen from Table 1, chlorinated hydrocarbons, organophosphates, and carbamates were first used for the suppression of CM. Frequent applications of pyrethroids began in 1980 due to their lower toxicity to mammals and strong initial effect on insects. Although they are more environmentally friendly and can be applied in low doses per unit, area resistance has been observed. Microbial insecticides and insect growth regulators have been mostly used since the 1980s but after several years of application, resistance to them also occured. Since 2000 there have been a couple of new active compounds (i.e., chlorantraniliprole, spinetoram) that meet the requirements of integrated pest management (IPM) programs.

Table 1. Review of registered insecticides to suppress codling moth from 1890 -current $[54,55]$ and time of resistance development according to the Arthropod Pesticide Resistance Database [56].

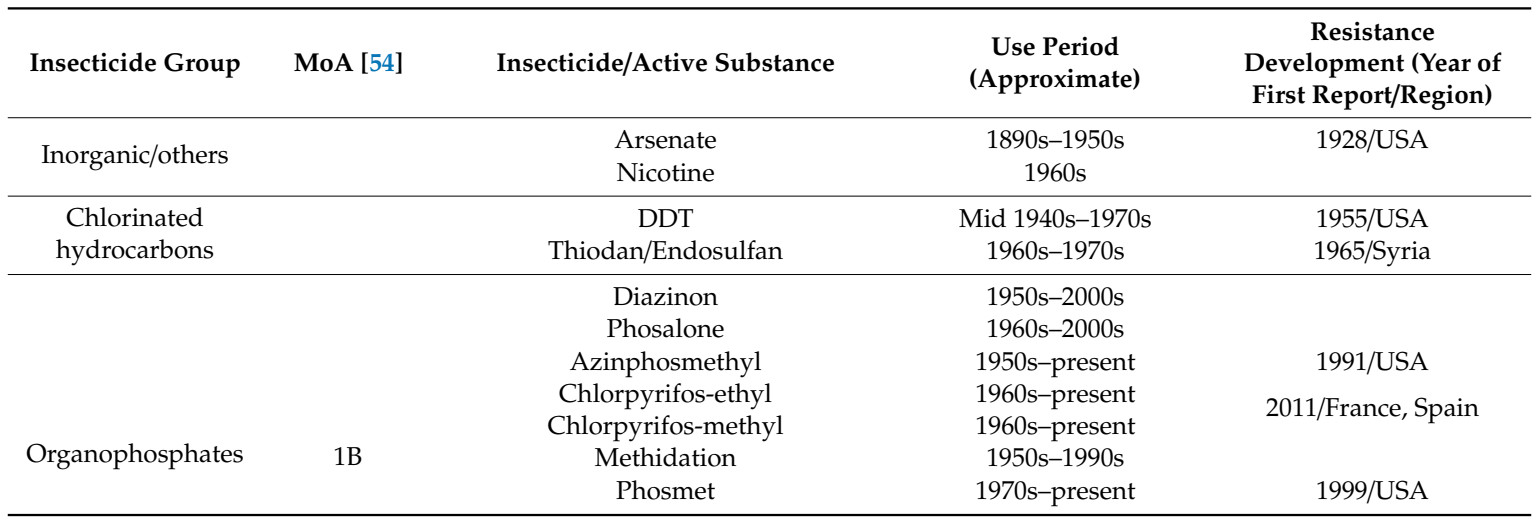


Table 1. Cont.

\begin{tabular}{|c|c|c|c|c|}
\hline Insecticide Group & MoA [54] & Insecticide/Active Substance & $\begin{array}{c}\text { Use Period } \\
\text { (Approximate) }\end{array}$ & $\begin{array}{c}\text { Resistance } \\
\text { Development (Year of } \\
\text { First Report/Region) }\end{array}$ \\
\hline & & Mevinphos & Mid 1950s-mid 1990s & \\
\hline & & Methomyl & 1970s-1990s & \\
\hline & & Oxamyl & Mid 1980s-1990s & \\
\hline & & Formetante hydrochloride & 1970s-1990s & \\
\hline Charbamates & $1 \mathrm{~A}$ & Carbaryl & 1970s-present & 2012/Spain \\
\hline \multirow{8}{*}{ Pyrethroids } & \multirow{8}{*}{$3 \mathrm{~A}$} & Fenvalerate/Esfenvalerate & 1970s-present & \multirow{8}{*}{ 2001/China } \\
\hline & & Permethrin & 1970s-present & \\
\hline & & Bifenthrin & 1980s-present & \\
\hline & & Deltametrin & 1970s-present & \\
\hline & & Flucythrinate & 1980s-present & \\
\hline & & Lambda-cyhalotrin & 1980s-present & \\
\hline & & Gama-cyhalotrin & 1980s-present & \\
\hline & & Tau-fluvalinate & 1980s-present & \\
\hline \multirow{2}{*}{$\begin{array}{c}\text { Microbial } \\
\text { insecticides }\end{array}$} & & Bacillus thuringiensis sub sp. kurstaki & 1980s-present & \multirow[b]{2}{*}{ 2007/Germany } \\
\hline & & Codling moth granulovirus (CpGV) & 1980s-present & \\
\hline Naturalites & 5 & Spinosad & 1990s-present & \\
\hline \multirow{5}{*}{$\begin{array}{l}\text { Insect growth } \\
\text { regulators }\end{array}$} & 15 & $\begin{array}{l}\text { Benzonylureas (diflubenzuron, } \\
\text { hexaflumuron, flufenoxuron, } \\
\text { triflumuron, lufenuron, } \\
\text { teflubenzuron) }\end{array}$ & 1970s-present & $\begin{array}{l}\text { diflubenzuron/1988/USA } \\
\text { triflumuron/1995/France } \\
\text { teflubenzuron/1995/France } \\
\text { flufenoxuron/2011/Spain }\end{array}$ \\
\hline & $7 \mathrm{~B}$ & Fenoxycarb & 1980s-present & 2007/Czechoslovakia \\
\hline & \multirow{2}{*}{18} & Tebufenozide & 1990s-present & \\
\hline & & Methoxyfenozide & 1990s-present & \multirow[t]{2}{*}{ 2008/USA } \\
\hline & $7 \mathrm{~B}$ & Pyriproxyfen & 2000-present & \\
\hline \multirow{3}{*}{ Nicotinoids } & \multirow{3}{*}{$4 \mathrm{~A}$} & Acetamiprid & 1990s-present & \multirow{3}{*}{$\begin{array}{l}\text { 2010/USA } \\
\text { 2011/Spain }\end{array}$} \\
\hline & & Thiacloprid & 2001-present & \\
\hline & & Thiamethoxam & 2001-present & \\
\hline Avermectins & 6 & Emamectin benzoate & 2000-present & \\
\hline $\begin{array}{l}\text { Anthranilic } \\
\text { diamide } \\
\text { insecticides }\end{array}$ & 28 & Chlorantraniliprole & 2007-present & \\
\hline Spinosyns & 5 & Spinetoram & 2011-present & \\
\hline
\end{tabular}

The classic model of CM suppression implies the intense application of aggressive chemical preparations, most commonly a wide spectrum of activity. Due to the altered biology of the CM (i.e., more generations/year) insecticides must be applied several times per season $[57,58]$. Some populations of CM have gained simultaneous resistance to several chemical subgroups of insecticides. In light of this and to delay resistance development, the rotation of compounds from different MoA groups ensures that repeated selection with compounds from any single MoA group is minimized. By rotation of insecticides across all available classes, selection pressure for the evolution of any type of resistance is minimized and the development of resistance will be delayed or prevented. The presence of $\mathrm{kdr}$ resistance renders pyrethroids less effective, whereas carbamates and organophosphates can still be used. In addition, the use of larvicides such as the organophosphate in conjunction with pyrethroids can support resistance management through rotation of MoA across different life stages. Effective long-term resistance management is important, but many factors have to be considered (including regional availability of insecticides). Currently, there are eight MoAs for CM control. In practice, it should not be difficult to implement rotation programs because there are enough active substances of insecticides in Europe that have mandated approval for CM. Alternatives to more persistent molecules are being developed [59,60]. For example, Bassi et al. [61] describe the development of a new compound, chlorantraniliprole, which belongs to a new class of selective insecticides. That makes chlorantraniliprole a valuable option for insecticide resistance management (IRM) strategies. Chlorantraniliprole is safe for key beneficial arthropods and honey bees, which renders it IPM compliant (i.e., excellent toxicity profile and use in low doses provide safety for consumers and agricultural workers). Nevertheless, there is a need for the improvement of alternative pest control methods, such as 
the application of microbial insecticides, mating disruptors or attract-and-kill methods. Production of high quality and healthy fruit that does not harm human health and the environment should continue to rely on an integrated production system where insecticide treatments must be applied responsibly and only when they are needed [62].

\subsection{Biological Control}

Biological control agents play a key role in most IPM strategies; these include entomopathogens, parasitoids and predators [63]. For augmentative biological control of CM, viruses such as granulovirus and entomopathogenic nematodes (EPNs) (Steinernema carpocapsae, Steinernema feltiae, Heterohabditis spp.) have been used as microbial agents [61].

The most widely used biopesticide is Bacillus thuringiensis (Bt) [64]. For controlling CM, Bt is very limited because of the improbability of ingesting a lethal dose of $B t$ toxin during feeding by neonate larvae [63]. On the other hand, granulovirus (GV) (Baculoviridae) is one of the most efficient and highly selective pathogens for suppression of CM. Its specificity for CM and safety to non-target organisms is documented by Lacey et al. [65]. It is one of the most virulent baculoviruses known. According to Laing and Jaques (1980) and Huber (1986), the $\mathrm{LD}_{50}$ for neonate larvae has been estimated at 1.2 to 17 granules/larva. The biggest disadvantage of CpGV is its sensitivity to solar radiation [66-68], and the need for frequent reapplication.

Parasitoids are insects whose larvae feed and develop within or on the bodies of other arthropods. Each parasitoid larva develops on a single individual and eventually kills that host [53]. Parasitoid wasps from the families Braconidae (Ascogaster quadridentata and Microdes rufipes), Ichneumonidae (Mastrus ridibundus and Liotryphon caudatus) and Trichogrammatidae (Trichogramma sp.) are the best known parasitoid species of CM. The parasitism of entomophagous wasps M. ridibundus and A. quadradentata has been successfully applied in CM control in some US states [63]. Species from Braconidae most commonly parasitize CM larvae, and Ichneumonidae parasitize CM larvae and adults and Trichogrammatidae parasitize eggs of Tortricidae moths. A reduction of 53-84\% of CM was achieved by the experimental release of two Trichogramma species (T. dendrolimi and T. embryophagum) in apple orchards in Germany [53]. An additional benefit of the release of parasitoids is the simultaneous control of other pest species in apple orchards. The beneficial organisms alone can play an effective role in IPM but in general, the effect on CM control in economically productive orchards is considered insufficient [69].

For biological control, the most promising EPN species for suppression of CM are from the families Steinernematidae and Heterorhabditidae [70]. Species from both families are obligatorily associated with symbiotic bacteria (Xenorhabdis spp. and Photorhabdis spp., respectively) which are known for quickly killing its host insect. The most promising results for CM control have been with Steinernema feltiae and Steinernema carpocapsae [71]. Cocooned overwintering CM larva is the life stage most practical to control using EPNs. That life stage occurs between late summer and early spring in cryptic habitats, such as underneath loose pieces of bark or in pruning wounds on trees [71]. Eliminating cocooned larvae would protect fruit from damage in the following growing season [72]. The main obstacles for successful CM control with EPNs are low fall temperatures and desiccation of the infective juvenile stage of EPNs before they have penetrated the host's cocoon.

Few studies exist on CM predators and biological antagonists. The largest group of CM predators are insects. Other important CM predators can be spiders, bats and birds [73-75]. In undisturbed habitats the eggs and neonate larvae of CM are most commonly preyed upon by small heteropteran insects, including: Anthocoridae, Miridae, Phytocoris sp., Diaphnidia sp., and Deraeocoris spp. Larger Carabidae and Dermaptera also play an important role [76]. The review of CM natural enemies and stages that are affected are summarized in Table 2. 
Table 2. Review of codling moth natural enemies and life stage attacked [63].

\begin{tabular}{|c|c|c|c|}
\hline Natural Enemies & Organism/Family & Family/Species & CM Life Stage Attacked \\
\hline \multirow{4}{*}{$\begin{array}{l}\text { Entomopathogenic } \\
\text { organisms }\end{array}$} & Virus & Granulovirus (CpGV) & Neonate larvae \\
\hline & Bacteria & Bacillus thurigiensis & Neonate larvae \\
\hline & Fungi & Beauveria bassiana & Cocooned overwintering larvae \\
\hline & Nematodes & $\begin{array}{l}\text { Steinernematidae } \\
\text { Heterorhabditidae }\end{array}$ & Cocooned overwintering larvae \\
\hline \multirow{14}{*}{ Predators } & Anthocoridae & Orius insidiosus & \multirow{6}{*}{ Eggs and neonate larvae } \\
\hline & Antnocorraae & Anthocoris musculus & \\
\hline & & Hyaliodes harti & \\
\hline & & Phytocoris sp. & \\
\hline & Miridae & Diaphnidia $\mathrm{sp}$ & \\
\hline & & $\begin{array}{c}\text { Blepharidopterus angulatus } \\
\text { Deraeocoris spp. }\end{array}$ & \\
\hline & Reduviidae & & \\
\hline & Nabidae & & Mature larvae \\
\hline & Carabidae, Trogossitidae, & & \\
\hline & $\begin{array}{c}\text { Malachiidae, Staphylinidae, } \\
\text { Cleridae, Cantharidae, } \\
\text { Elateridae }\end{array}$ & & Cocooned larvae \\
\hline & Formicidae & & Mature larvae \\
\hline & Phlaeothripidae & Haplothrips faurei & \\
\hline & 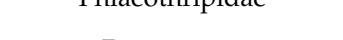 & Leptothrips mali & Eggs \\
\hline & Dermaptera & Forficula auricularia & \\
\hline \multirow{5}{*}{ Parasitoids } & Braconidae & $\begin{array}{l}\text { Ascogaster quadridentata } \\
\text { Microdes rufipes }\end{array}$ & Larvae \\
\hline & \multirow{3}{*}{ Ichneumonidae } & Mastrus ridibundus & Jarue and adultc \\
\hline & & Liotryphon caudatus & Larvae and aunls \\
\hline & & Pimpla turionellae & Pupae \\
\hline & Trichogrammatidae & Trichogramma sp. & Eggs \\
\hline
\end{tabular}

Part of biological control is also ecological engineering, which includes the manipulation of farm habitats to be less favorable for arthropod pests and more attractive to beneficial insects [77]. To increase the activity of EPNs, ecological engineering encourages the use of environmental modification with mulches and irrigation [63]. Mulching is a strategy for conserving water and it is likely to become increasingly important for long-term sustainability in orchards [78]. In support of mulch, compared with bare ground, it may enhance CM control by providing cocooning sites for larvae, in a substrate that is easy to treat, maintains moisture and enhances nematode activity $[72,79,80]$. De Wall et al. [81] investigated the potential of using the EPN Heterorhabditis zealandica in combination with different mulch types (pine chips, wheat straw, pine wood shavings, blackwood and apple wood chips) to control diapausing CM. Their results showed that highest CM mortality was when they used pine wood shavings as mulch (88\%) compared to pine chips, wheat straw, blackwood and apple wood chips (41-88\%). Importantly, their research showed that humidity had to be maintained above $95 \%$ for at least 3 days to ensure nematode survival.

\subsection{Population Genetic Monitoring}

Analysis of population genetic structure is a key aspect in understanding insect pest population dynamics in agriculture [82]. The development of effective pest management strategies relies on a multidisciplinary approach [83] and one component of this is knowledge of the population genetics of the pest. Genetic structure and patterns of dispersal at the local and landscape scale are important for establishing a control strategy for insect pests [84]. Understanding the population genetics of $\mathrm{CM}$ invasions enables identification of the geographic origin, number of introduction events and the spread of the infestation [85]. According to Keil et al. [86] CM populations are composed of mobile and sedentary genotypes and this has direct consequences for the local observable population dynamics of the species as well as the implementation of new behavior-based pest management measures (e.g., mating disruption, attract-and-kill and SIT technique) [87]. The first attempt to elucidate the population genetic structure of $\mathrm{CM}$ on a global geographic scale (i.e., inter-continental) using allozymes 
was conducted by Pashley and Bush [88]. These authors showed that CM populations were not differentiated among countries investigated $\left(\mathrm{F}_{\mathrm{ST}}\right.$ : 0.05). Following this, Bues and Toubon [89] used the same approach to study populations in Switzerland and France. More recently, Timm et al. [90] and Thaler et al. [7] used amplified fragment length polymorphism (AFLP) markers to study the molecular phylogeny and genetic structure of CM where they found large differences among these populations ( $\mathrm{F}_{\mathrm{ST}}$ : 0.70). More recently, co-dominant microsatellite markers from CM were developed by Zhou et al. [91] who characterized 17 loci. An additional 24 microsatellite loci were characterized by Frank et al. [92], with these loci most frequently used in population genetic studies worldwide $[6,15,82,84,93]$.

Franck et al. [6] used those markers to investigate the genetic structure of CM populations from 27 orchards from three continents (Europe, Asia and South America) to determine the dynamics of CM meta-populations and the impact that human activities had on these dynamics. Franck et al. [6] showed that populations of CM are structured by geographic distance on the intercontinental level. However, analyses of CM populations from treated and untreated orchards in Europe and South America (France and Chile) did not show significant genetic differentiation by country, but rather a pattern of minor influence of insecticide treatments on allelic richness. A similar comparison of CM genetic structure from treated versus untreated populations using microsatellite markers (following Franck et al. [6]) was conducted in Croatia [15]. Even though differences in genetic structure among populations were low and not statistically significant, untreated populations of CM had the highest average number of alleles and the largest number of unique alleles compared to treated populations. Overall, the study's findings suggested a possible reduction of allelic richness in treated populations due to the frequent application of insecticides. The authors have questioned whether these genetic changes may relate to the increase in reproductive abilities of CM and a change in its overall biology in Croatia [15].

Frank and Timm [82] also used microsatellite markers to study CM genetic structure and gene flow from organic versus treated apple orchards. They found low genetic variation between populations but significant partitioning of genetic variation within individuals. Chen and Dorn [93] used nine microsatellite markers to investigate genetic differentiation and the amount of gene flow between populations from orchards in Switzerland and laboratory populations. They noted significant genetic differentiation among populations from apple, apricot and walnut orchards and also between populations collected from orchards that were less than $10 \mathrm{~km}$ apart. These results are consistent with Timm et al. [90] and Thaler et al. [7] and provide significant evidence for CM population differentiation at small spatial scales, even within the same bio-region. Fuentes-Contreras et al. [94] found significant but weak genetic differentiation between populations across time and space comparisons. These authors found no significant correlation ( $\mathrm{r}:-0.03 ; p$ : 0.56$)$ between genetic distance and geographic distance of the studied populations and the lack of structure at a local scale with frequent adult movement between treated and untreated orchards. Also, their data highlights the importance of developing area-wide management programs for successful CM control. Men et al. [95] used eight microsatellite loci to infer the characteristics of genetic diversity and genetic structure of $12 \mathrm{CM}$ populations collected from the main distribution regions (Xinjiang, Gansu and Heilongjiang Provinces) in China and compared them with one German and one Swiss population.

They found ascertained loss of genetic diversity and important structuring related to distribution, however no important correlation between genetic distance and geographic distance among populations (F $\mathrm{F}_{\mathrm{ST}}$ : 0.22091) was found. Voudouris et al. [96] used 11 microsatellite loci to analyze nine CM populations from Greece and six from France for comparison. Results from Bayesian clustering and genetic distance analyses separated CM populations in two genetic clusters. In agreement with previous published studies $\mathrm{F}_{\mathrm{ST}}$ values showed low genetic differentiation among populations (Greek populations $\mathrm{F}_{\mathrm{ST}}$ : 0.009 and $\mathrm{F}_{\mathrm{ST}}$ : 0.0150 French populations).

Dispersal of fertilized females is important because it directly affects the effectiveness of pest control programs. Margaritopoulos et al. [97] used the mark-release-recapture (MRR) method on male and female individuals from two laboratory and one wild CM populations. Kinship analysis was 
made on 303 genotyped individuals (11 microsatellite loci) from two contiguous apple orchards to see the dispersal patterns in the Greek CM populations. The collected data confirm the view of the sedentary nature of $\mathrm{CM}$ and indicate that genotypes able to migrate at long distances are not present in the studied area. The information obtained could be fundamental for determining the dynamics and genetics of the pest populations and for developing efficient management programs. Results about the dispersal pattern of codling moths might have practical applications in mating disruption or mass trapping pest control programs.

\subsection{Area-Wide Integrated Pest Management}

The 5-year CAMP (CM Area-Wide Management Program) was the first of the area-wide programs initiated by the US Department of Agriculture [98]. Demonstration of this was initiated in 1995 in a multi-institutional program created through the collaboration of university and government researchers in Washington, Oregon and California. The goal of this program was to implement, assess, research and educate industry users about promising new IPM technologies. CAMP was highly successful in fueling the rapid adoption of a new paradigm in orchard pest management that resulted in significant reduction in fruit injury using nearly $80 \%$ less broad-spectrum insecticides [95].

IPM is based on environmentally and toxicological acceptable treatments. Using pheromones, attract-and-kill methods and mating disruption results in a promising way of controlling CM. According to Witzgall et al. [99], orchard treatments with up to $100 \mathrm{~g}$ of synthetic pheromone per hectare effectively control CM populations over the entire growing season. The disadvantage of these techniques is that females are not affected [100].

After Roelofs et al. [101] identified the main pheromone components for CM attraction (i.e., E8, E10-dodecadienol (codlemone)), pheromone traps started to be a useful tool for insect detection and monitoring and later for its suppression. Mating disruption is based on tactics to employ synthetic sex pheromones that interfere with the ability of males in finding female moths and as a control strategy it shows considerable promise. Currently, it is used to suppress CM populations in over 160,000 ha of apple and pear orchards worldwide [99]. The first commercially available pheromone dispenser for control of CM was Isomate- ${ }^{\circledR}$, which became available in the USA in 1991 [55]. Monitoring of $\mathrm{CM}$ in orchards treated with sex pheromone mating disruption (MD) has become widely adopted and is very important for its effective management [99]. Traps used for monitoring are baited with the sex pheromone (E,E)-8,10-dodecadien-1-ol (codlemone) that attracts males [102] and ethyl (E,Z)-2,4-decadieonate, a pear-derived kairomone, to attract both sexes of CM [103]. The combination of pear ester with codlemone (PH-PE) in a lure is effective for monitoring both sexes of codling moth in sex pheromone-treated orchards. Monitoring females, instead of only male $\mathrm{CM}$, has certain benefits, like egg density and timing of egg hatch. A number of studies have used pear ester's attractiveness for both male and female CM to develop alternative approaches to further enhance the catch of female moths [104-106]. Using pear ester with acetic acid (AA) can increase moth catches, especially of females [107]. The co-emission of acetic acid improves the capture performance of pear ester in clear traps to levels equivalent to the PH-PE lure when used in orchards treated with sex pheromone dispensers [108]. The effectiveness of this mating disruption as a technique depends on numerous factors (shape, size, isolation and environment of orchards) as well as the starting density of the CM population itself. In order for mating disruption to be successful there is a need for low CM population levels and a reliable monitoring system [109]. Mating disruption for CM began in the US in 1995 in large contiguous apple blocks (400 ha) and small private orchards [110]. According to Witzgall et al. [99] and Casado et al. [111], Europe also does not lag far behind in its application of this technique. In Croatia, this method is not widely used, although the first field trials in 1999 and 2000 [112] were promising and did reduce the number of insecticides being used during those growing seasons. Barić and Pajač Živković [113] showed that the highest protection efficacy was achieved with $92.65 \%$ control in the standard part of the orchard, and the efficacy of mating disruption was $67.65 \%$ and $73.53 \%$. Although the authors concluded that this method of control was not economically justifiable given 
the high cost (approx. $150 € /$ ha) of protection and first-class fruit losses. However, their results also confirmed that the mating disruption method must be combined with the application of two insecticide treatments to increase the efficacy and profitability of apple production. Miller and Gut [114] agree that pest control by mating disruption is an important and growing industry. This combined control of $\mathrm{CM}$ is more ecologically oriented and also meets the toxicological minimum requirements of the food suppliers and the food retail chain. They propose some key economic and policy questions that will require the collective efforts of scientists and society as a whole if the benefits of mating disruption are to be maximized. There is still a lot of work to be done to optimize the role of mating disruption as one of the components of modern integrated pest management.

Mass trapping, as one of the first mating control strategies, can significantly reduce CM damage levels. However, several intensive field studies have shown that it is not effective enough for CM control because of the low damage thresholds (no more than 1-2\% of the crop) required in commercial apple growing. Since adequate control cannot be achieved by using only mass trapping, there is a need for combining it with other control measures [115]. Another problem is the cost and practical difficulties of deploying sufficient trapping stations. If droplets containing sex pheromones and a fast-acting insecticide are used instead of traps [116], then the costs can be substantially reduced. The potential strength of the approach is that males have been removed from the system, stopping their ability to find a mate.

The attract-and-kill method, in its technically simplest form is the attractant applied as a 'tank-mix' with an insecticide. This method uses the same attractants as mass trapping but in an envelope impregnated with an insecticide on the outside. This technology has shown efficacy in the control of several important lepidopteran pests including pink bollworm, Pectinophora gossypiella (Saunders), light brown apple moth, Epiphyas postvittana (Walker), and CM [117]. In both systems, mass trapping and attract-and-kill, chemicals are utilized only when the population increases considerably [118].

For AW-IPM the integration of sterile insects is a very effective and environmentally friendly control tactic that can be combined with other control practices and offers great potential [119,120]. Sterile insect technique (SIT) is non-destructive to the environment, does not affect non-target organisms, and can easily be integrated with other biological control methods such as parasitoids, predators and pathogens [121]. The technique has gained traction in the last few decades [122,123]. SIT is an autocidal pest control technique that controls pests with a form of birth control [121]. The target pest species is mass-reared, sterilized through the use of gamma radiation and then released in the target area in high numbers. After release, sterile males will locate and mate with wild females and transfer the infertile sperm thus reducing the wild population. Another method of sterilization is genetic manipulation or sexing strains, where lethal mutations are incorporated into sperm [121]. The SIT, together with mating disruption, granulosis virus and EPNs, are the options that offer great potential as cost-effective additions to accessible management techniques for AW-IPM approaches.

In Table 3, a review of changes in the suppression of CM through the last two decades and factors that affect the current scenario in comparison to the year 2000 is shown. Reduction of chemical control measures due to EU regulations and food chain pressures, increased adoption of semiochemicals for mating disruption, and microbial insecticides contributed to the suppression of CM. Improved investigation tools for resistance detection and confirmatory assays have contributed to the decrease of field resistance issues and better knowledge of resistance. 
Table 3. Changes in codling moth control from 2000 until now (modified according to IRAC [54]).

\begin{tabular}{cccc}
\hline & $\mathbf{2 0 0 0}$ & $\mathbf{2 0 1 2}$ & $\mathbf{2 0 1 7}$ \\
\hline No. of MoA available for codling moth control * & 8 & 10 & 11 \\
No. of individual insecticides available & High & Decreasing & Fewer \\
Use of semiochemicals (mating disruption) & Minor & Moderate & Increasing \\
Microbial insecticides & Minor & Moderate & Moderate \\
Biological control & Minor & Minor & Minor \\
Regulatory pressure & Low & High & Decreasing \\
Food chain pressure & Low & High & Decreasing \\
Field resistance issues ***** & Moderate & Decreasing & Low \\
Resistance knowledge and investigation tools & Moderate & Increasing & High \\
\hline
\end{tabular}

* According to IRAC Mode of Action (MoA) classification, four MoA were introduced from 1997-2000, and two during 2007-2010. ${ }^{* *}$ Number of individual insecticides available is decreasing every year. The criteria introduced in the revision of EU Directive 91/414 may concern a significant number of available insecticides, with an impact on sustainable control options. ${ }^{* * *}$ Dependent on the implementation of the other factors. The assumption is that sustainable insecticide use will continue to be possible and implemented. In this respect, increased use of non-chemical tools will play a key role.

\section{Resistance Management Strategies}

The most effective strategy to combat insecticide resistance is to do everything possible to prevent it from occurring in the first place. To this end, crop specialists recommend insect resistance management (IRM) programs as one part of a larger (IPM) approach covering three basic components: monitoring pest complexes in the field for changes in population density, focusing on economic injury levels and integrating multiple control strategies. IRM is the scientific approach of managing pests long term and preventing or delaying pest evolution towards pesticide resistance and minimizing the negative impacts of resistance on agriculture [124]. The basic strategy for IRM is to incorporate as many different control strategies as possible for particular pests including the use of synthetic insecticides, biological insecticides, beneficial insects (predators/parasitoids), cultural practices, transgenic plants (where allowed), crop rotation, pest-resistant crop varieties, and chemical attractants or deterrents. The establishment of an anti-resistance program in perennial crops is slightly more difficult than in arable crops where crop rotation is possible. If non-chemical methods provide satisfactory pest control, preference should be given to them over chemical methods. Key insect pests of apple and grape such as $\mathrm{CM}$ and grapevine moths are effectively controlled via mating disruption. In Switzerland, mating disruption is in use in $50 \%$ of the apple orchards and $60 \%$ of vineyards, and this has enabled a reduction of synthetic pesticide use by two thirds [125].

Insecticides, if necessary, must be selected with care and their impact on future pest populations considered. Broad-spectrum insecticides should always be avoided when a more specific insecticide will suffice. Even cultural practices, such as irrigation for destroying overwintering stages (e.g., cotton bollworm, Helicoverpa armigera) of pests can play a role in managing resistance [126]. When insecticide is applied it should be timed correctly and for the best efficacy, it should target the most vulnerable life stage of the insect pest. It is important to mix and apply insecticides carefully. With the increasing problem of resistance, there is no space for error in terms of insecticide dose, timing, coverage, etc.

Reducing doses, application frequency, and resorting to the partial application of pesticides contribute to the IPM goal of reducing or minimizing risks to human health and the environment. Regular monitoring for insecticide resistance is essential to react proactively to prevent insecticide resistance from compromising control [127].

Before applying any $\mathrm{CM}$ control action, it is necessary to monitor CM occurrence and early infestation of apples. Pheromone traps are used in orchards to determine the present amount of adult male moths. For estimating the potential infestation risk of the second generation, it is recommended to examine 1000 young apples in June for damage or the presence of CM [128]. Spray thresholds are also based on the number of moths in the pheromone traps or on infestation rates detected in the harvest of the current or last season. For apples, the economic threshold for the CM is $1 \%$ of infested fruit [55]. 
Figure 1 shows recommendations for effective $\mathrm{CM}$ control and resistance management based on current knowledge: I. to monitor; II. application of ecotoxicological favorable protection measures like mating disruption (when CM population levels are low); III. application of chemical control measurements (if necessary); and IV. control of overwintering stages by applying biological agents (e.g., $\mathrm{CpGV}$, nematodes) to reduce the late summer and fall CM population in order to minimize the population in the following growing season. It is an effective example of how resistance management should work in orchards (Figure 1).

\section{RESISTANCE MANAGEMENT}

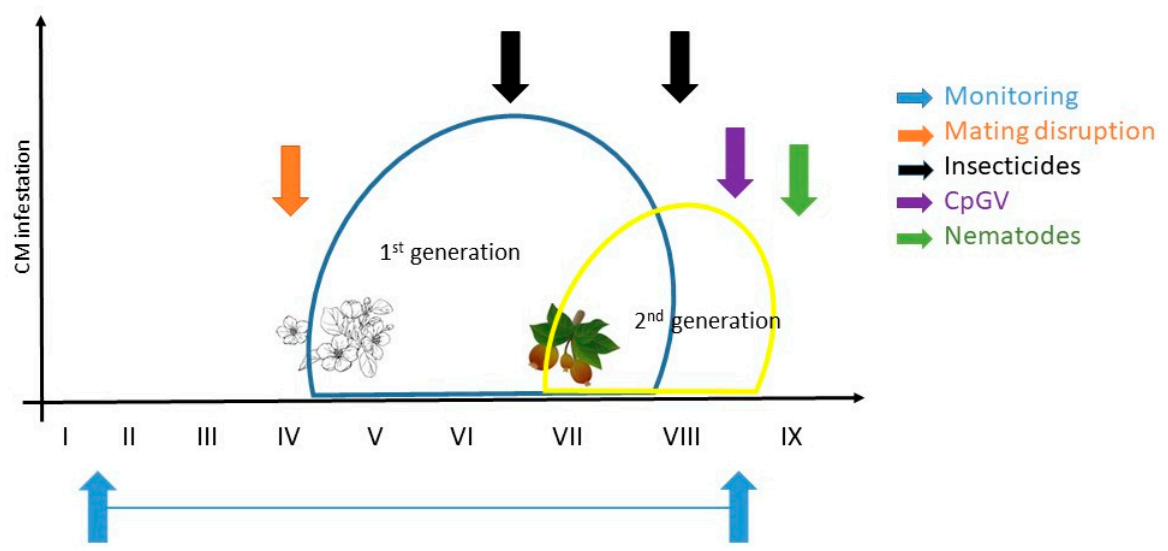

Figure 1. Example of resistance management for codling moth; the ideal control is a combination of different measures (modified by Martina Kadoić Balaško).

\section{Perspectives in Codling Moth Resistance Detection}

Reliable data on resistance are essential to successful resistance management. Bioassay is a method used for evaluating the status of resistance in insect populations. Effective resistance management relies on sound information about the extent and intensity of resistance problems [128]. There are several different bioassay methods to monitor for $\mathrm{CM}$ resistance, such as diagnosing metabolic resistance using differential enzymatic activity between life-stages within the same population. The analysis of the enzymatic activity (MFO, GST, EST) in a CM population is a key element for resistance evaluation [54]. In the last decade, large-scale monitoring for field resistance mostly relied on topical application to diapausing codling moth larvae. Recent studies have confirmed their validity for IGRs but questioned their reliability for the prediction of field resistance with some neurotoxic insecticides [54]. Bioassay of the target-stage includes resistance monitoring done on the target instar. For larvicidal products, ingestion bioassays on neonate larvae (F1 or F2 of the feral population), IRAC method no. 017, normally provide a more reliable indication of the field situation than topical application to diapausing larvae [54].

So far, the only approved method for CM sensitivity monitoring is IRAC method 017 [54]. This method is specifically recommended by the IRAC Diamide Working Group for evaluating the susceptibility status of diamide insecticides (IRAC MoA 28). Also, it is suitable for the following insecticide classes (IRAC MoA class): organophosphate (1B), pyrethroid (3A), neonicotinoids (4A), spinosyn (5), avermectin (6), juvenile hormone mimics (7A), fenoxycarb (7B), benzyl urea (15), diacylhydrazine (18), indoxacarb (22A), metaflumizone (22B), and pyridalyl (un) [54]. According to this method, the first step is to collect a representative sample of insects from a field. These may be larvae, pupae or adults for rearing to the appropriate stage from which an F1 population for testing can be reared. A minimum of 100 larvae or diapausing pupae should be collected for each population to be tested, to establish a breeding colony of at least 50 adults. When we have enough CM larvae for the bioassay, the second step is to prepare an accurate dilution of the test compound from the identified commercial product. Six evenly spaced rates allowing a clear dose-response are 
recommended [54]. For this method, a single neonate (less than $24 \mathrm{~h}$ old) of CM larvae should be used. In the case of diamide insecticides, organophosphates (1B), pyrethroids (3A), neonicotinoids (4A), spinosyns (5), avermectins (6), indoxacarb (22A), metaflumizone (22B) and pyridalyl (un), a final assessment of larval mortalities (dead and live) is made after $96 \mathrm{~h}$. For juvenile hormone mimics (7A), fenoxycarb (7B), benzyl urea (15) and diacylhydrazine (18), a 120-h assessment period should be used. Also, larvae should go through full molt before the mortality assessment [54]. The number of dead larvae and moribund larvae (seriously affected larvae which are unable to make coordinated movement and cannot return to an upright position when turned upon their backs with a seeking pin or fine-pointed forceps) are to be summed and considered as dead. Results should be expressed as percentage mortalities, correcting for "untreated" (control) mortalities using Abbott's formula [54].

Through innovation it is possible to establish reliable strategies for detecting resistant CM populations. Of most importance is the timely detection of resistant populations in order to suppress them and prevent further spread of resistance. For this purpose, exploration of existing tools, though with novel use as monitoring tools, is warranted (i.e., geometric morphometrics and population genomics).

Geometric morphometrics (GM) offers a powerful method for studying intraspecific variation or ecotypes and it has been shown to be a useful bio-monitoring tool [129]. It is known that metric properties (wing shape and size) are the first morphological characters to change as influenced by environmental and genetic factors $[130,131]$. This therefore makes them an ideal technique to detect and monitor population variation and resistant variants in the field [132,133]. Furthermore, the use of GM generates important new data on basic insect biology and ecology.

Recently, wing or body shape and size has been used as a population bio-marker to detect: differences between susceptible and resistant variants [134]; population changes related to invasion [135]; and morphological differences in resistant versus non-resistant populations and rotation versus Btresistant strains of western corn rootworm [136]. GM was tested as an existing method, though novel in its application, for morphological differences in field-insect pest populations versus laboratory populations and integrated versus ecological populations in Croatia. That is, Pajač Živković et al. [137] revealed two noticeable wing shape morphotypes in Drosophila suzukii (i.e., vein configuration) between grape and strawberry crops. Different IPM practices in agro-ecosystems generate different degrees of disturbance in insect communities, as shown by Benitez et al. [138] where shape variation and fluctuating asymmetry levels were estimated by applying GM methods to the beetle Pterostichus melas melas.

Specifically, for CM, Khaghaninia et al. [139] used GM methods as tools to show significant differences in $\mathrm{CM}$ fore and hindwings as a function of season (overwintered vs. summer), geographic location and sex. Also, Pajač Živković et al. [140] investigated the relationship between different pest management types and CM morphology using GM. The authors detected population changes related to different types of apple production. The aforementioned publications provide compelling evidence for the use of GM as a population bio-marker when applied to CM and other insect pest monitoring.

Recent enhancements with the speed, cost and accuracy of next generation sequencing are revolutionizing the discovery of single nucleotide polymorphisms (SNPs) and field of population genomics. SNPs are increasingly being employed as the marker of choice in the molecular ecology toolkit in non-model organisms. SNPs are attractive markers for many reasons [141,142], including: the availability of high numbers of annotated markers; low-scoring error rates; relative ease of calibration among laboratories compared to length-based markers; and the associated ability to assemble combined temporal and spatial data sets from multiple laboratories.

SNPs are single base substitutions found at a single genomic locus. Although they have lower allelic diversity and provide less statistical power to discriminate unique genotypes, they have a denser and uniform distribution within genomes which makes them very useful for population genetic studies. In recent times, SNPs have become an affordable and readily accessible means of generating a lot of data quickly for non-model species [143]. Genotyping of SNPs has potentially far-reaching applications 
in insect population genomics. SNP detection has facilitated association mapping studies in many insect species including: Drosophila melanogaster [144], D. v. virgifera [145], Aedes aegypti [146], Glossina fuscipes [147], Diatraea saccharalis [148], Phaulacridium vittatum [149] and other insects in which specific nucleotides are statistically associated with complex phenotypic traits. Detailed genomic data could provide an answer about genetically conditioned resistance development in insects. By combining genetic and GM population monitoring, it may be possible to identify the addition or deletion of alleles and different haplotypes, and the genetic and morphometric patterns which have developed under the selective pressure of control.

\section{Conclusions}

$\mathrm{CM}$ is the most harmful insect species of the Tortricidae family that causes economic damage to apple production worldwide. The suppression of this pest in the past relied on intensive insecticide application(s) which ultimately led to the development of resistance and caused a decrease in population of beneficial species which were once the only natural regulators of pest populations in apple farming. One of the basic goals of integrated production is growing high quality and healthy fruits that contain minimal residues of pesticides; such production is safer for human health and the environment. To achieve this goal, environmentally friendly area-wide IPM strategies must be established. This involves the use of pheromones and kairomones (attract-and-kill methods and mating disruption) and sterile males (SIT technique) which combined with the use of natural enemies (mainly viruses and nematodes) serve as good alternatives to chemicals. Also, recent advancements in the use of mechanical protection measures against CM (insect-proof nets) have shown very promising results in field trials. All available control measures against $\mathrm{CM}$ should be used in combination and there should be an informed and systematic strategy for their use. Effective IRM strategies should involve all available tools for pest control (e.g., natural enemies, biotechnical tools, alternative insecticides) and make a concerted effort to trial and use existing technologies, though with novel applications (e.g., GM for monitoring population phenotypic changes and SNPs for monitoring population genetic changes) for their monitoring, therefore fulfilling the best practice resistance management strategy discussed here.

Author Contributions: Conceptualization, K.M.M., D.L., I.P.Ž., M.K.B.; methodology, R.B., K.M.M., D.L. and I.P.Ž.; resources, R.B., K.M.M., D.L. and I.P.Ž.; data Curation, R.B., K.M.M. and D.L.; writing-Original Draft preparation, M.K.B., D.L., K.M.M., R.B. and I.P.Ž.; writing-review \& editing, M.K.B., D.L., I.P.Ž. and K.M.M. All authors have read and agreed to the published version of the manuscript.

Funding: This review was supported by the Croatian Science Foundation through the project Monitoring of Insect Pest Resistance: Novel Approach for Detection, and Effective Resistance Management Strategies (MONPERES) and Young researchers' career development project-training of new doctoral students.

Acknowledgments: The authors thank all collaborators on the projects, coauthors on publications, colleagues, students, and technical staff who contributed to the CM research.

Conflicts of Interest: The authors declare no conflicts of interest.

\section{References}

1. Ciglar, I. Integrirana Zaštita Voćaka i Vinove Loze, 1st ed.; Zrinski: Čakovec, Croatia, 1998; pp. 82-87.

2. Balachowsky, A.; Mesnil, L. Les Insectes Nuisibles Aux Plantes Cultivées; Ministère de L' Agriculture: Paris, France, 1935; pp. 130-158.

3. Kovačević, Ž. Applied Entomology, 2nd ed.; University of Zagreb: Zagreb, Croatia, 1952; pp. 312-319.

4. Slingerland, M.V. Codling moth in New England in 1750. N. Y. Agric. Exp. 1898, 142, 85-155.

5. Zhang, X.Z. Taxonomic notes on the codling moth, Carpocapsa pomonella L. In Sinkiang. Acta Entomol. Sin. 1957, 7, 467-472.

6. Franck, P.; Reyes, M.; Olivares, J.; Sauphanor, B. Genetic architecture in codling moth populations: Comparison between microsatellite and insecticide resistance markers. Mol. Ecol. 2007, 16, 3554-3564. [CrossRef] [PubMed] 
7. Thaler, R.; Brandstätter, A.; Meraner, A.; Chabicovski, M.; Parson, W.; Zelger, R.; Dalla Via, J.; Dallinger, R. Molecular phylogeny and population structure of the codling moth (Cydia pomonella) in Central Europe: II. AFLP analysis refl ects human-aided local adaptation of a global pest species. Mol. Phylogenet. Evol. 2008, 48, 838-849. [CrossRef]

8. Maceljski, M. Jabučni savijač (Cydia/Laspeyresia, Carpocapsa, Grapholita/ pomonella L.). In Poljoprivredna Entomologija, 2nd ed.; Zrinski: Čakovec, Croatia, 2002; pp. 302-309.

9. Alford, D.V. A Color Atlas of Fruit Pests Their Recognition, Biology, and Control; Wolfe Publishing: Prescott, AZ, USA, 1984.

10. Wildbolz, T. Über Möglichkeiten der Prognose und Befallsüberwachung und Über Toleranzgrenzen bei der Integrierten Schädlingsbekämpfung im Obstbau. Entomophaga 1962, 7, 273-283. [CrossRef]

11. Higbee, B.S.; Calkins, C.O.; Temple, C.A. Overwintering of codling moth (Lepidoptera: Tortricidae) larvae in apple harvest bins and subsequent moth emergence. J. Econ. Entomol. 2001, 94, 1511-1517. [CrossRef]

12. Meraner, A.; Brandstätter, A.; Thaler, R.; Aray, B.; Unterlechner, M.; Niederstätter, H.; Parson, W.; Zelger, R.; Dalla Via, J.; Dallinger, R. Molecular phylogeny and population structure of the codling moth (Cydia pomonella) in Central Europe: I. Ancient clade splitting revealed by mitochondrial haplotype markers. Mol. Phylogenet. Evol. 2008, 48, 825-837. [CrossRef]

13. Neven, L.G. Fate of codling moth (Lepidoptera: Tortricidae) in harvested apples held under short photoperiod. J. Econ. Entomol. 2012, 105, 297-303. [CrossRef]

14. Neven, L.G. Effects of short photoperiod on codling moth diapause and survival. J. Econ. Entomol. 2013, 106, 520-523. [CrossRef]

15. Pajač, I.; Barić, B.; Mikac, K.M.; Pejić, I. New insights into the biology and ecology of Cydia pomonella from apple orchards in Croatia. Bull. Insectol. 2012, 65, 185-193.

16. Geier, P.W. The life history of codling moth, Cydia pomonella (L.) (Lepidoptera:Tortricidae), in the Australian capital territory. Aust. J. Zool. 1963, 11, 323-367. [CrossRef]

17. Pajač, I.; Barić, B. The behaviour of codling moth (Lepidoptera: Tortricidae) in the Croatian apple orchards. IOBC/WPRS Bull. 2012, 74, 79-82.

18. Sauphanor, B.; Brosse, V.; Bouvier, J.C.; Speich, P.; Micoud, A.; Martinet, C. Monitoring resistance to diflubenzuron and deltamethrin in French codling moth populations (Cydia pomonella). Pest Manag. Sci. 2000, 56, 74-82. [CrossRef]

19. Boivin, T.; Chabert D'Hières, C.; Bouvier, J.C.; Beslay, D.; Sauphanor, B. Pleiotropy of insecticide resistance in the codling moth, Cydia pomonella. Entomol. Exp. Appl. 2001, 99, 381-386. [CrossRef]

20. Bouvier, J.C.; Buès, R.; Boivin, T.; Boudinhon, L.; Beslay, D.; Sauphanor, B. Deltamethrin resistance in the codling moth (Lepidoptera: Tortricidae): Inheritance and number of genes involved. Heredity 2001, 87, 456-462. [CrossRef]

21. May, R.M.; Dobson, A.P. Population dynamics and the rate of evolution of pesticide resistance. In Pesticide Resistance: Strategies and Tactics for Management; National Academy Press: Washington, DC, USA, 1986; pp. 170-193.

22. Hough, W.S. Relative resistance to arsenical poisoning of two codling moth strains. J. Econ. Entomol. 1928, 21, 325-329. [CrossRef]

23. Thwaite, W.G.; Williams, D.G.; Hately, A.M. Extent and significance of azinphos-methyl resistance in codling moth in Australia. Pest Control. Sustain. Agric. 1993, 93, 166-168.

24. Sauphanor, B.; Bouvier, J.C.; Brosse, V. Spectrum of insecticide resistance in Cydia pomonella (Lepidoptera: Tortricidae) in South-eastern France. J. Econ. Entomol. 1998, 91, 1225-1231. [CrossRef]

25. Reuveny, H.; Cohen, E. Resistance of the codling moth Cydia pomonella (L.) (Lep Tortricidae) to pesticides in Israel. J. Appl. Entomol. 2004, 128, 645-651. [CrossRef]

26. Sauphanor, B.; Cuany, A.; Bouvier, J.C.; Brosse, V.; Amichot, M.; Berge, J.B. Mechanism of resistance to deltametrin in Cydia pomonella (L.) (Lepidoptera: Tortricidae). Pestic. Biochem. Physiol. 1997, 58, 109-117. [CrossRef]

27. Stara, J.; Nad'ova, K.; Kocourek, F. Insecticide resistance in the codling moth (Cydia pomonella). J. Fruit Ornam. Plant Res. 2006, 14, 99-106.

28. Reyes, M.; Franck, P.; Charmillot, P.J.; Ioriatti, C.; Olivares, J.; Pasqualini, E.; Sauphanor, B. Diversity of insecticide resistance mechanisms and spectrum in European populations of the codling moth, Cydia pomonella. Pest Manag. Sci. 2007, 63, 890-902. [CrossRef] [PubMed] 
29. Reyes, M.; Barros-Parada, W.; Ramírez, C.C.; Fuentes-Contreras, E. Organophosphate resistance and its main mechanism in populations of codling moth (Lepidoptera: Tortricidae) from Central Chile. J. Econ. Entomol. 2015, 108, 277-285. [CrossRef] [PubMed]

30. Bush, M.R.; Abdel-All, Y.A.; Rock, G.C. Parathion resistance and esterase activity in codling moth (Lepidoptera: Tortricidae) from North Carolina. J. Econ. Entomol. 1993, 86, 660-666. [CrossRef]

31. Brun-Barale, A.; Bouvier, J.C.; Pauron, D.; Bergé, J.B.; Sauphanor, B. Involvement of a sodium channel mutation in pyrethroid resistance in Cydia pomonella L., and development of a diagnostic test. Pest Manag. Sci. 2005, 61, 549-554. [CrossRef]

32. Cassanelli, S.; Reyes, M.; Rault, M.; Manicardi, G.C.; Sauphanor, B. Acetylcholinesterase mutation in an insecticide-resistant population of the codling moth Cydia pomonella (L.). Insect Biochem. Mol. Biol. 2006, 36, 642-653. [CrossRef]

33. Pajač, I.; Barić, B.; Šimon, S.; Mikac, K.M.; Pejić, I. An initial examination of the population genetic structure of Cydia pomonella (Lepidoptera: Tortricidae) in Croatian apple orchards. J. Food Agric. Environ. 2011, 9, 459-464.

34. Bosch, D.; Rodríguez, M.A.; Avilla, J. Monitoring resistance of Cydia pomonella (L.) Spanish field populations to new chemical insecticides and the mechanisms involved. Pest Manag. Sci. 2018, 74, 933-943. [CrossRef]

35. Yang, X.Q.; Zhang, Y.L. Investigation of insecticide-resistance status of Cydia pomonella in Chinese populations. Bull. Entomol. Res. 2015, 105, 316-325. [CrossRef]

36. Voudouris, C.C.; Sauphanor, B.; Franck, P.; Reyes, M.; Mamuris, Z.; Tsitsipis, J.A.; Vontas, J.; Margaritopoulos, J.T. Insecticide resistance status of the codling moth Cydia pomonella (Lepidoptera: Tortricidae) from Greece. Pestic. Biochem. Physiol. 2011, 100, 229-238. [CrossRef]

37. Herniou, E.A.; Luque, T.; Chen, X.; Vlak, J.M.; Winstanley, D.; Cory, J.S.; O’Reilly, D.R. Use of whole genome sequence data to infer baculovirus phylogeny. J. Virol. 2001, 75, 8117-8126. [CrossRef] [PubMed]

38. Harrison, R.L.; Hoover, K. Baculoviruses and other occluded insect viruses. In Insect Pathology, 2nd ed.; Vega, F.E., Kaya, H.K., Eds.; Academic Press: London, UK, 2012; pp. 73-131.

39. Falcon, L.A.; Kane, W.R.; Bethell, R.S. Preliminary evaluation of a granulosis virus for control of the codling moth. J. Econ. Entomol. 1968, 61, 1208-1213. [CrossRef]

40. Huber, J.; Dickler, E. Codling moth granulosis virus: It's efficiency in the field in comparison with organophosphorus insecticides. J. Econ. Entomol. 1977, 70, 557-561. [CrossRef]

41. Asser-Kaiser, S.; Fritsch, E.; Undorf-Spahn, K.; Kienzle, J.; Eberle, K.E.; Gund, N.A.; Reineke, A.; Zebitz, C.P.W.; Heckel, D.G.; Huber, J.; et al. Rapid emergence of baculovirus resistance in codling moth due to dominant, sex-linked inheritance. Science 2007, 317, 1916-1918. [CrossRef] [PubMed]

42. Eberle, K.E.; Jehle, J.A. Field resistance of codling moth against Cydia pomonella granulovirus (CpGV) is autosomal and incompletely dominant inherited. J. Invertebr. Pathol. 2006, 93, 201-206. [CrossRef] [PubMed]

43. Schmitt, A.; Bisutti, I.L.; Ladurner, E.; Benuzzi, M.; Sauphanor, B.; Kienzle, J.; Zingg, D.; Undorf-Spahn, K.; Fritsch, E.; Huber, J.; et al. The occurrence and distribution of resistance of codling moth to Cydia pomonella granulovirus in Europe. J. Appl. Entomol. 2013, 137, 641-649. [CrossRef]

44. Zichová, T.; Stará, J.; Kundu, J.K.; Eberle, K.E.; Jehle, J.A. Resistance to Cydia pomonella granulovirus follows a geographically widely distributed inheritance type within Europe. Biocontrol 2013, 58, 525-534. [CrossRef]

45. Schulze-Bopp, S.; Jehle, J.A. Development of a direct test of baculovirus resistance in wild codling moth populations. J. Appl. Entomol. 2013, 137, 153-160. [CrossRef]

46. Sauer, A.J.; Fritsch, E.; Undorf-Spahn, K.; Nguyen, P.; Marec, F.; Heckel, D.G.; Jehle, J.A. Novel resistance to Cydia pomonella granulovirus $(\mathrm{CpGV})$ in codling moth shows autosomal and dominant inheritance and confers cross-resistance to different CpGV genome groups. PLoS ONE 2017, 12, e0179157. [CrossRef]

47. Sauer, A.J.; Schulze-Bopp, S.; Fritsch, E.; Undorf-Spahn, K.; Jehle, J.A. A third type of resistance to Cydia pomonella granulovirus in codling moths shows a mixed Z-linked and autosomal inheritance pattern. Appl. Environ. Microbiol. 2017, 83, e01036-17. [CrossRef]

48. Alaphilippe, A.; Capowiez, Y.; Severac, G.; Simon, S.; Saudreau, M.; Caruso, S.; Vergnani, S. Codling moth exclusion netting: An overview of French and Italian experiences. IOBC-WPRS Bull. 2016, 112, 31-35.

49. Pajač Živković, I.; Jemrić, T.; Fruk, M.; Buhin, J.; Barić, B. Influence of different netting structures on codling moth and apple fruit damages in northwest Croatia. Agric. Conspec. Sci. 2016, 81, 99-102.

50. Tasin, M.; Demaria, D.; Ryne, C.; Cesano, A.; Galliano, A.; Anfora, G.; Ioriatti, C.; Alma, A. Effect of anti-hail nets on Cydia pomonella behavior in apple orchards. Entomol. Exp. Appl. 2008, 129, 32-36. [CrossRef] 
51. Sauphanor, B.; Severac, G.; Maugin, S.; Toubon, J.F.; Capowiez, Y. Exclusion netting may alter reproduction of the codling moth (Cydia pomonella) and prevent associated fruit damage to apple orchards. Entomol. Exp. Appl. 2012, 145, 134-142. [CrossRef]

52. Baiamonte, I.; Raffo, A.; Nardo, N.; Moneta, E.; Peparaio, M.; D'Aloise, A.; Kelderer, M.; Casera, C.; Paoletti, F. Effect of the use of anti-hail nets on codling moth (Cydia pomonella) and organoleptic quality of apple (cv. Braeburn) grown in Alto Adige Region (northern Italy). J. Sci. Food Agric. 2016, 96, 2025-2032. [CrossRef]

53. Sauer, A.J. Novel Types of Resistance of Codling Moth to Cydia pomonella Granulovirus. Ph.D. Thesis, Technische Universität, Darmstadt, Germany, 2017.

54. Insecticide Resistance Action Committee (IRAC). Codling Moth, Cydia pomonella. Available online: https: //www.irac-online.org/pests/cydia-pomonella (accessed on 20 August 2019).

55. Beers, E.H.; Stuckling, D.M.; Prokopy, R.J.; Avila, J. Ecology and management of apple arthropod pests. In Apples: Botany, Production and Uses, 1st ed.; Ferree, D.C., Warrington, I.J., Eds.; CABI Publishing: Wallingford, UK, 2003; pp. 489-514.

56. Arthropod Pesticide Resistance Database (APRD). Cydia pomonella-Shown Resistance to Active Ingredient(s). Available online: https://www.pesticideresistance.org/display.php?page=species\&arId=407 (accessed on 30 August 2019).

57. Gonzalez, D.C. Cydia pomonella (L.) Behavior and Responses to Host Volatiles. Ph.D. Thesis, Department de Quimica, Universitat de Lleida, Lleida, Spain, 2007.

58. Lacey, L.A.; Thomson, D.; Vincent, C.; Arthurs, S.P. Codling moth granulovirus: A comprehensive review. Biocontrol Sci. Technol. 2008, 18, 639-663. [CrossRef]

59. Czaja, K.; Góralczyk, K.; Struciński, P.; Hernik, A.; Korcz, W.; Minorczyk, M.; Łyczewska, M.; Ludwicki, J.K. Biopesticides-towards increased consumer safety in the European Union. Pest Manag. Sci. 2015, 71, 3-6. [CrossRef]

60. Gerwick, B.C.; Sparks, T.C. Natural products for pest control: An analysis of their role, value and future. Pest Manag. Sci. 2014, 70, 1169-1185. [CrossRef]

61. Bassi, A.; Rison, J.L.; Wiles, J.A. Chlorantraniliprole (DPX-E2Y45, Rynaxypyr ${ }^{\circledR}$, Coragen ${ }^{\circledR}$ ), a new diamide insecticide for control of codling moth (Cydia pomonella), Colorado potato beetle (Leptinotarsa decemlineata) and European grapevine moth (Lobesia botrana). Nova Goric. 2009, 4, 39-45.

62. Pajač Živković, I.; Barić, B. Rezistentnost jabukova savijača na insekticidne pripravke. Glas. Biljn. Zaštite 2017, 17, 469-479.

63. Lacey, L.A.; Unruh, T.R. Biological control of codling moth (Cydia pomonella, Lepidoptera: Tortricidae) and its role in integrated pest management, with emphasis on entomopathogens. Vedalia 2005, 12, 33-60.

64. Lacey, L.A.; Frutos, R.; Kaya, H.K.; Vail, P. Insect pathogens as biological control agents: Do they have a future? Biol. Contr. 2001, 21, 230-248. [CrossRef]

65. Lacey, L.A.; Arthurs, S.P.; Headrick, H. Comparative activity of the codling moth granulovirus against Grapholita molesta and Cydia pomonella (Lepidoptera: Tortricidae). J. Entomol. Soc. Br. Columbia 2005, 102, 79-80.

66. Arthurs, S.P.; Lacey, L.A. Field evaluation of commercial formulations of the codling moth granulovirus (CpGV): Persistence of activity and success of seasonal applications against natural infestations in the Pacific Northwest. Biol. Control 2004, 31, 388-397. [CrossRef]

67. Lacey, L.A.; Arthurs, S.P.; Knight, A.; Becker, K.; Headrick, H. Efficacy of codling moth granulovirus: Effect of adjuvants on persistence of activity and comparison with other larvicides in a Pacific Northwest apple orchard. J. Entomol. Sci. 2004, 39, 500-513. [CrossRef]

68. Lacey, L.A.; Arthurs, S.P. New method for testing solar sensitivity of commercial formulations of the granulovirus of codling moth (Cydia pomonella, Tortricidae: Lepidoptera). J. Invertebr. Pathol. 2005, 90, 85-90. [CrossRef]

69. Thorpe, P.T.; Pryke, J.S.; Samways, M.J. Review of ecological and conservation perspectives on future options for arthropod management in Cape Floristic Region pome fruit orchards. Afr. Entomol. 2016, 24, 279-306. [CrossRef]

70. Georgis, R.; Koppenhöfer, A.; Lacey, L.; Belair, G.; Duncan, L.; Grewal, P.; Samish, M.; Torr, P.; van Tol, R. Successes and failures of entomopathogenic nematodes. Biol. Contr. 2006, 38, 103-123. [CrossRef] 
71. Lacey, L.A.; Unruh, T.R. Entomopathogenic nematodes for control of codling moth: Effect of nematode species, dosage, temperature and humidity under laboratory and simulated field conditions. Biol. Contr. 1998, 13, 190-197. [CrossRef]

72. Lacey, L.A.; Granatstein, D.; Arthurs, S.P.; Headrick, H.; Fritts, J.R. Use of entomopathogenic nematodes (Steinernematidae) in conjunction with mulches for control of overwintering codling moth (Lepidoptera: Tortricidae). J. Entomol. Sci. 2006, 41, 107-119. [CrossRef]

73. Glen, D.M. The effects of predators on the eggs of codling moth Cydia pomonella, in a cider apple orchard in Southwest England. Ann. Appl. Biol. 1975, 80, 115-119. [CrossRef]

74. Wearing, C.H. Integrated control of apple pests in New Zealand: 10 Population dynamics of codling moth in Nelson. N. Z. J. Zool. 1979, 6, 165-199. [CrossRef]

75. Hogan, B.C. A Study of Bat Foraging Activity and Its Relation to Codling Moth Activity on Four Yolo County Walnut Orchards. Master's Thesis, California State University, Sacramento, CA, USA, 2000.

76. Riddick, E.W.; Mills, N.J. Potential of adult carabids (Coleoptera: Carabidae) as predators of fifth-instar codling moth (Lepidoptera: Tortricidae) in apple orchards in California. Environ. Entomol. 1994, 23, 1338-1345. [CrossRef]

77. Gurr, G.M.; Wratten, S.D.; Altieri, M.A. Ecological engineering: A new direction for agricultural pest management. AFBM J. 2004, 1, 25-31.

78. Granatstein, D.; Mullinix, K. Mulching options for Northwest organic and conventional orchards. HortScience 2008, 43, 45-50. [CrossRef]

79. Lacey, L.A.; Shapiro-Ilan, D.I.; Glenn, G.M. Post-application of anti-desiccant agents improves efficacy of entomopathogenic nematodes in formulated host cadavers or aqueous suspension against diapausing codling moth larvae (Lepidoptera: Tortricidae). Biocontrol Sci. Technol. 2010, 20, 909-921. [CrossRef]

80. Navaneethan, T.; Strauch, O.; Besse, S.; Bonhomme, A.; Ehlers, R.U. Influence of humidity and a surfactant-polymer-formulation on the control potential of the entomopathogenic nematode Steinernema feltiae against diapausing codling moth larvae (Cydia pomonella L.) (Lepidoptera: Tortricidae). BioControl 2010, 55, 777-788. [CrossRef]

81. De Waal, J.Y.; Malan, A.P.; Addison, M.F. Evaluating mulches together with Heterorhabditis zealandica (Rhabditida: Heterorhabditidae) for the control of diapausing codling moth larvae, Cydia pomonella (L.) (Lepidoptera: Tortricidae). Biocontrol Sci. Technol. 2011, 21, 255-270. [CrossRef]

82. Franck, P.; Timm, A.E. Population genetic structure of Cydia pomonella: A review and case study comparing spatiotemporal variation. J. Appl. Entomol. 2010, 134, 191-200. [CrossRef]

83. Blommers, L.H. Integrated pest management in European apple orchards. Annu. Rev. Entomol. 1994, 39, 213-241. [CrossRef]

84. Fuentes-Contreras, E.; Espinoza, J.L.; Lavandero, B.; Ramírez, C.C. Population genetic structure of codling moth (Lepidoptera: Tortricidae) from apple orchards in central Chile. J. Econ. Entomol. 2008, 101, 190-198. [CrossRef] [PubMed]

85. Roderick, G.K. Geographic structure of insect populations: Gene flow, phylogeography, and their uses. Annu. Rev. Entomol. 1996, 41, 325-352. [CrossRef] [PubMed]

86. Keil, S.; Gu, H.; Dorn, S. Response of Cydia pomonella to selection on mobility: Laboratory evaluation and field verifi caion. Ecol. Entomol. 2001, 26, 495-501. [CrossRef]

87. Dorn, S.; Schumacher, P.; Abivardy, C.; Meyhofer, R. Global and regional pest insects and their antagonists in orchards: Spatial dynamics. Agric. Ecosyst. Environ. 1999, 73, 111-118. [CrossRef]

88. Pashley, D.P.; Bush, G.L. The use of allozymes in studying insect movement with special reference to the codling moth, Laspeyresia pomonella. In Movement of Highly Mobile Insects: Concepts and Methodology in Research, 1st ed.; Rabb, R.L., Kennedy, G.G., Eds.; North Carolina State University Press: Raleigh, NC, USA, 1979; pp. 333-341.

89. Bues, R.; Toubon, J.F.; Poitout, H.S. Variabilite ecophysiologique et enzymatique de Cydia pomonella L. en fonction de l'origine geographique et de la plante hote. Agronomie 1995, 15, 221-231. [CrossRef]

90. Timm, A.E.; Geertsema, H.; Warnich, L. Gene flow among Cydia pomonella (Lepidoptera: Tortricidae) geographic and host populations in South Africa. J. Econ. Entomol. 2006, 99, 341-348. [CrossRef] [PubMed]

91. Zhou, Y.H.; Gu, H.N.; Dorn, S. Isolation of microsatellite loci in the codling moth Cydia pomonella (Lepidoptera: Tortricidae). Mol. Ecol. Notes 2005, 5, 226-227. [CrossRef] 
92. Franck, P.; Guérin, F.; Loiseau, A.; Sauphanor, B. Isolation and characterization of microsatellite loci in the codling moth Cydia pomonella (Lepidoptera: Tortricidae). Mol. Ecol. Notes 2005, 5, 99-102. [CrossRef]

93. Chen, M.H.; Dorn, S. Microsatellites reveal genetic differentiation among populations in an insect species with high genetic variability in dispersal, the codling moth, Cydia pomonella (L.) (Lepidoptera: Tortricidae). Bull. Entomol. Res. 2010, 100, 75-81. [CrossRef]

94. Fuentes-Contreras, E.; Basoalto, E.; Franck, P.; Lavandero, B.; Knight, A.L.; Ramírez, C.C. Measuring local genetic variability in populations of codling moth (Lepidoptera: Tortricidae) across an unmanaged and commercial orchard interface. Environ. Entomol. 2014, 43, 520-527. [CrossRef]

95. Men, Q.L.; Chen, M.H.; Zhang, Y.L.; Feng, J.N. Genetic structure and diversity of a newly invasive species, the codling moth, Cydia pomonella (L.) (Lepidoptera: Tortricidae) in China. Biol. Invasions 2013, 15, 447-458. [CrossRef]

96. Voudouris, C.; Franck, P.; Olivares, J.; Sauphanor, B.; Mamuris, Z.; Tsitsipis, J.; Margaritopoulos, J. Comparing the genetic structure of codling moth Cydia pomonella (L.) from Greece and France: Long distance gene-flow in a sedentary pest species. Bull. Entomol. Res. 2012, 102, 185-198. [CrossRef] [PubMed]

97. Margaritopoulos, J.T.; Voudouris, C.C.; Olivares, J.; Sauphanor, B.; Mamuris, Z.; Tsitsipis, J.A.; Franck, P. Dispersal ability in codling moth: Mark-release-recapture experiments and kinship analysis. Agric. For. Entomol. 2012, 14, 399-407. [CrossRef]

98. Knight, A.L. Codling moth areawide integrated pest management. In Areawide Pest Management: Theory and Implementation, 1st ed.; Koul, O., Cuperus, G., Elliott, N., Eds.; CAB International: Oxfordshire, UK, 2008; pp. 159-190.

99. Witzgall, P.; Stelinski, L.; Gut, L.; Thomson, D. Codling moth management and chemical ecology. Annu. Rev. Entomol. 2008, 53, 503-522. [CrossRef] [PubMed]

100. Yan, F.; Bengtsson, M.; Witzgall, P. Behavioral response of female Codling Moths, Cydia Pomonella, to apple volatiles. J. Chem. Ecol. 1999, 25, 1343-1351. [CrossRef]

101. Roelofs, W.; Comeau, A.; Hill, A.; Milicevic, G. Sex attractant of the codling moth: Characterization with electroantennogram technique. Science 1971, 174, 297-299. [CrossRef] [PubMed]

102. Knight, A.L.; Light, D.M. Timing of egg hatch by early-season codling moth (Lepidoptera: Tortricidae) predicted by moth catch in pear ester-and codlemone-baited traps. Can. Entomol. 2005, 137, 728-738. [CrossRef]

103. Light, D.M.; Knight, A.L.; Henrick, C.A.; Rajapaska, D.; Lingren, B.; Dickens, J.C.; Reynolds, K.M.; Buttery, R.G.; Merrill, G.; Roitman, J.; et al. A pear-derived kairomone with pheromonal potency that attracts male and female codling moth, Cydia pomonella (L.). Naturwissenschaften 2001, 88, 333-338. [CrossRef]

104. Knight, A.L.; Hilton, R.; Light, D.M. Monitoring codling moth (Lepidoptera: Tortricidae) in apple with blends of ethyl (E,Z)-2,4-decadienoate and codlemone. Environ. Entomol. 2005, 34, 598-603. [CrossRef]

105. Mitchell, V.J.; Manning, L.A.; Cole, L.; Suckling, D.M.; El-Sayed, A.M. Efficacy of the pear ester as a monitoring tool for codling moth Cydia pomonella (Lepidoptera: Tortricidae) in New Zealand apple orchards. Pest Manag. Sci. 2008, 64, 209-214. [CrossRef]

106. Joshi, N.K.; Hull, L.A.; Rajotte, E.G.; Krawczyk, G.; Bohnenblust, E. Evaluating sex-pheromone-and kairomone-based lures for attracting codling moth adults in mating disruption versus conventionally managed apple orchards in Pennsylvania. Pest Manag. Sci. 2011, 67, 1332-1337. [CrossRef] [PubMed]

107. Landolt, P.J.; Suckling, D.M.; Judd, G.J.R. Positive interaction of a feeding attractant and a host kairomone for trapping the codling moth, Cydia pomonella (L.). J. Chem. Ecol. 2007, 33, 2236-2244. [CrossRef] [PubMed]

108. Knight, A.L.; Light, D.M.; Trimble, R.M. Identifying (E)-4,8-dimethyl-1,3,7-nonatriene plus acetic acid as a new lure for male and female codling moth (Lepidoptera: Tortricidae). Environ. Entomol. 2011, 40, 420-430. [CrossRef]

109. Fernández, D.E.; Cichón, L.; Garrido, S.; Ribes-Dasi, M.; Avilla, J. Comparison of lures loaded with codlemone and pear ester for capturing codling moths, Cydia pomonella, in apple and pear orchards using mating disruption. J. Insect Sci. 2010, 10, 139. [CrossRef]

110. Thomson, D.; Jenkins, J. Successes with area-wide mating disruption: Moving from crisis management to sustainable pheromone-based pest management. In Proceedings of the IOBC/WPRS Working Group Pheromones and Other Semiochemicals in Integrated Production, Bursa, Turkey, 1-5 October 2012; Tasin, M., Kovanci, O.B., Eds.; International Organization for Biological and Integrated Control of Noxious Animals and Plants (OIBC/OILB). West Palaearctic Regional Section (WPRS/SROP): Dijon, France, 2014. 
111. Casado, D.; Cave, F.; Welter, S. (Puffer ${ }^{\circledR}-C M$ Dispensers for mating disruption of codling moth: Area of influence and impacts on trap finding success by males. Puffer ${ }^{\circledR}-C M$ Dispensers for mating disruption of codling moth: Area of influence and impacts on trap finding success by males. IOBC/WPRS Bull. 2014, 99, 25-31.

112. Ciglar, I.; Barić, B.; Tomšić, T.; Šubić, M. Control of codling moth (Cydia pomonella) by mating disruption technique. Agron. Glas. 2000, 63, 85-93.

113. Barić, B.; Pajač Živković, I. The efficacy of mating disruption in the control of codling moth in Croatia, with special reference to the costs. Pomol. Croat. Glas. Hrvat. Agron. Društva 2017, 21, 125-132.

114. Miller, J.R.; Gut, L.J. Mating disruption for the 21st century: Matching technology with mechanism. Environ. Entomol. 2015, 44, 427-453. [CrossRef]

115. Lösel, P.M.; Penners, G.; Potting, R.P.; Ebbinghaus, D.; Elbert, A.; Scherkenbeck, J. Laboratory and field experiments towards the development of an attract and kill strategy for the control of the codling moth, Cydia pomonella. Entomol. Exp. Appl. 2000, 95, 39-46. [CrossRef]

116. Charmillot, P.J.; Pasquier, D.; Scalco, A.; Hofer, D. Studies on the control of the codling moth Cydia pomonella L. using attractant-insecticide. Mitt. Schweiz. Entomol. Ges. 1996, 69, 431-439.

117. Mansour, M. Attract and kill for codling moth Cydia pomonella (Linnaeus) (Lepidoptera: Tortricidae) control in Syria. J. Appl. Entomol. 2010, 134, 234-242. [CrossRef]

118. Damos, P.; Colomar, L.A.; Ioriatti, C. Integrated fruit production and pest management in Europe: The apple case study and how far we are from the original concept? Insects 2015, 6, 626-657. [CrossRef] [PubMed]

119. Klassen, W. Area-wide integrated pest management and the sterile insect technique. In Sterile Insect Technique. Principles and Practice in Area-wide Integrated Pest Management, 1st ed.; Dyck, V.A., Hendrichs, J., Robinson, A.S., Eds.; Springer: Dordrecht, The Netherlands, 2005; pp. 39-68.

120. Vreysen, M.J.B.; Robinson, A.S.; Hendrichs, J. Areawide control of insect pests. From research to field implementation. In Sterile Insect Technique. Principles and Practice in Area-Wide Integrated Pest Management, 1st ed.; Dyck, V.A., Hendrichs, J., Robinson, A.S., Eds.; Springer: Dordrecht, The Netherlands, 2005; pp. 351-353.

121. Vreysen, M.J.B.; Carpenter, J.E.; Marec, F. Improvement of the sterile insect technique for codling moth Cydia pomonella (Linnaeus) (Lepidoptera Tortricidae) to facilitate expansion of field application. J. Appl. Entomol. 2010, 134, 165-181. [CrossRef]

122. Bloem, K.A.; Bloem, S.; Carpenter, J.E. Impact of moth suppression/eradication programmes using the sterile insect technique or inherited sterility. In Sterile Insect Technique. PRINCIPLES and Practice in Area-Wide Integrated Pest Management, 1st ed.; Dyck, V.A., Hendrichs, J., Robinson, A.S., Eds.; Springer: Dordrecht, The Netherlands, 2005; pp. 677-700.

123. Dyck, V.A.; Hendrichs, J.; Robinson, A.S. Public Relations and Political Support in Area-Wide Integrated Pest Management Programmes that Integrate the Sterile Insect Technique. In Sterile Insect Technique. Principles and Practice in Area-Wide Integrated Pest Management, 1st ed.; Dyck, V.A., Hendrichs, J., Robinson, A.S., Eds.; Springer: Dordrecht, The Netherlands, 2005; pp. 524-545.

124. Joshi, N.K.; Rajotte, E.G.; Naithani, K.J.; Krawczyk, G.; Hull, L.A. Population dynamics and flight phenology model of codling moth differ between commercial and abandoned apple orchard ecosystems. Front. Physiol. 2016, 7, 408. [CrossRef] [PubMed]

125. Onstad, D. Major Issues in Insect Resistance Management. In Insect Resistance Management, Biology, Economics and Prediction, 2nd ed.; Onstad, D., Ed.; Academic Press: Cambridge, MA, USA, 2007; pp. 1-16.

126. Yu, F.L.; Wu, G.; Liu, T.J.; Zhai, B.P.; Chen, F.J. Effects of irrigation on the performance of cotton bollworm, Helicoverpa armigera (Hübner) during different pupal stages. Int. J. Pest Manag. 2008, 54, 137-142. [CrossRef]

127. Barzman, M.; Bàrberi, P.; Birch, A.N.E.; Boonekamp, P.; Dachbrodt-Saaydeh, S.; Graf, B.; Hommel, B.; Jensen, J.E.; Kiss, J.; Kudsk, P.; et al. Eight principles of integrated pest management. Agron. Sustain. Dev. 2015, 35, 1199-1215. [CrossRef]

128. Insecticide Resistance Action Committee (IRAC). Resistance Management for Sustainable Agriculture and Improved Public Health, 2nd ed. 2010. Available online: http://www.irac-online.org/wp-content/uploads/ 2009/09/VM-Layout-v2.6_LR.pdf (accessed on 20 August 2019).

129. Hood, C.S. Geometric morphometric approaches to the study of sexual size dimorphism in mammals. Hystrix 2000, 11, 77-90. 
130. Levine, E.; Oloumi-Sadeghi, H. Western corn rootworm (Coleoptera: Chrysomelidae) larval injury to corn grown for seed production following soybeans grown for seed production. J. Econ. Entomol. 1996, 89, 1010-1016. [CrossRef]

131. Bouyer, J.; Ravel, S.; Dujardin, J.P.; De Meeus, T.; Via, L.; Thévenon, S.; Guerrini, L.; Sidibé, I.; Solano, P. Population structuring of Glossina palpalis gambiensis (Diptera: Glossinidae) according to landscape fragmentation in the Mouhoun river, Burkina Faso. J. Med. Entomol. 2007, 44, 788-795. [CrossRef]

132. Benitez, A.H.; Lemić, D.; Bažok, R.; Gallardo-Araya, M.C.; Mikac, M.K. Evolutionary Directional Asymmetry and Shape Variation in Diabrotica v. virgifera (Coleoptera: Chrysomelidae): An example using hind wings. Biol. J. Linn. Soc. 2014, 111, 110-118. [CrossRef]

133. Lemic, D.; Benitez, H.A.; Bazok, R. Intercontinental effect on sexual shape dimorphism and allometric relationships in the beetle pest Diabrotica virgifera virgifera LeConte (Coleoptera: Chrysomelidae). Zool. Anz. 2014, 253, 203-206. [CrossRef]

134. Mikac, K.M.; Douglas, J.; Spencer, J.L. Wing shape and size of the western corn rootworm (Coleoptera: Chrysomelidae) is related to sex and resistance to soybean-maize crop rotation. J. Econ. Entomol. 2013, 106, 1517-1524. [CrossRef] [PubMed]

135. Mikac, K.M.; Lemic, D.; Bažok, R.; Benítez, H.A. Wing shape changes: A morphological view of the Diabrotica virgifera virgifera European invasion. Biol. Invasions 2016, 18, 3401-3407. [CrossRef]

136. Mikac, K.M.; Lemic, D.; Benítez, H.A.; Bažok, R. Changes in corn rootworm wing morphology are related to resistance development. J. Pest Sci. 2019, 92, 443-451. [CrossRef]

137. Pajač Živković, I.; Lemic, D.; Mešić, A.; Barić, B.; Órdenes, R.; Benítez, H.A. Effect of fruit host on wing morphology in Drosophila suzukii (Diptera: Drosophilidae): A first view using geometric morphometrics. Entomol. Res. 2018, 48, 262-268. [CrossRef]

138. Benítez, H.A.; Lemic, D.; Püschel, T.A.; Gašparić, H.V.; Kos, T.; Barić, B.; Bažok, R.; Živković, I.P. Fluctuating asymmetry indicates levels of disturbance between agricultural productions: An example in Croatian population of Pterostichus melas melas (Coleptera: Carabidae). Zool. Anz. 2018, 276, 42-49. [CrossRef]

139. Khaghaninia, S.; Mohammadi, S.A.; Sarafrazi, A.M.; Iraninejad, K.H.; Ebrahimi, E.; Zahiri, R. An analysis of seasonal dimorphism in codling moths, Cydia pomonella, from Iran using geometric morphometrics. Bull. Insectol. 2014, 67, 43-50.

140. PajačŽivković, I.; Benitez, H.A.; Barić, B.; Bažok, R.; Drmić, Z.; Mrganić, M.; Lemić, D. Analysis of Croatian Cydia pomonella L. (Lepidoptera: Tortricidae) population variability by using geometric morphometrics. In Proceedings of the European Congress of Entomology, ECE, Napoli, Italy, 2-6 July 2018; Dallai, R., Ed.; Event Planet: Naples, Italy, 2018; pp. 180-181.

141. Brumfield, R.T.; Beerli, P.; Nickerson, D.A.; Edwards, S.V. The utility of single nucleotide polymorphisms in inferences of population history. Trends Ecol. Evol. 2003, 18, 249-256. [CrossRef]

142. Morin, P.A.; Luikart, G.; Wayne, R.K. SNPs in ecology, evolution and conservation. Trends Ecol. Evol. 2004, 19, 208-216. [CrossRef]

143. Xing, C.; Schumacher, F.R.; Xing, G.; Lu, Q.; Wang, T.; Elston, R.C. Comparison of microsatellites, single-nucleotide polymorphisms (SNPs) and composite markers derived from SNPs in linkage analysis. BMC Genet. 2005, 6, S29. [CrossRef]

144. Genissel, A.; Pastinen, T.; Dowell, A.; Mackay, T.F.; Long, A.D. No evidence for an association between common nonsynonymous polymorphisms in Delta and bristle number variation in natural and laboratory populations of Drosophila melanogaster. Genetics 2004, 166, 291-306. [CrossRef] [PubMed]

145. Coates, B.S.; Sumerford, D.V.; Miller, N.J.; Kim, K.S.; Sappington, T.W.; Siegfried, B.D.; Lewis, L.C. Comparative performance of single nucleotide polymorphism and microsatellite markers for population genetic analysis. J. Hered. 2009, 100, 556-564. [CrossRef] [PubMed]

146. Kotsakiozi, P.; Evans, B.R.; Gloria-Soria, A.; Kamgang, B.; Mayanja, M.; Lutwama, J.; Le Goff, G.; Ayala, D.; Paupy, C.; Badolo, A.; et al. Population structure of a vector of human diseases: Aedes aegypti in its ancestral range, Africa. Ecol. Evol. 2018, 8, 7835-7848. [CrossRef] [PubMed]

147. Saarman, N.P.; Opiro, R.; Hyseni, C.; Echodu, R.; Opiyo, E.A.; Dion, K.; Johnson, T.; Aksoy, S.; Caccone, A. The population genomics of multiple tsetse fly (Glossina fuscipes fuscipes) admixture zones in Uganda. Mol. Ecol. 2019, 28, 66-85. [CrossRef] 
148. Francischini, F.J.; Cordeiro, E.M.; de Campos, J.B.; Alves-Pereira, A.; Viana, J.P.G.; Wu, X.; Wei, W.; Brown, P.; Joyce, A.; Murua, G.; et al. Diatraea saccharalis history of colonization in the Americas. The case for human-mediated dispersal. PLoS ONE 2019, 14, e0220031. [CrossRef]

149. Yadav, S.; Stow, A.J.; Dudaniec, R.Y. Detection of environmental and morphological adaptation despite high landscape genetic connectivity in a pest grasshopper (Phaulacridium vittatum). Mol. Ecol. 2019, 8, 3395-3412. [CrossRef]

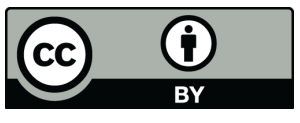

(C) 2020 by the authors. Licensee MDPI, Basel, Switzerland. This article is an open access article distributed under the terms and conditions of the Creative Commons Attribution (CC BY) license (http://creativecommons.org/licenses/by/4.0/). 